\title{
Hak Milik Atas Tanah Adat Di Wilayah Kepulauan
}

\section{Mispa Christian Science Paisina ${ }^{1}$, Adonia Ivone Laturette ${ }^{2,}$ Novyta Uktolseja ${ }^{3}$}

1,2,3 Fakultas Hukum Universitas Pattimura, Ambon, Indonesia.

@ : paisinamispa@gmail.com ${ }^{1}$

: $x x x x x x x x x x x x x x x x$

Info Artikel
Keywords:
Right of Ownership;
Indigenous Peoples;
Customary Land.

Kata Kunci:

Hak Milik; Masyarakat Adat; Tanah Adat.

\begin{abstract}
Introductioan: The Western Seram Islands have various customary rights that grow and develop in the lives of indigenous peoples and it becomes a rule that is believed by them, so that it becomes a law that binds them in determining their ownership rights to their customary land.

Purposes of the Research: This study aims to determine how the position of customary land ownership rights in the national land law system, and what is the legal basis and the way in which customary land ownership rights occur according to customary law.

Methods of the Research: This study uses the normative legal research method, which aims to find out how the position of ownership rights over customary land in the national land law system in the areas of Taniwel Timur, Negeri Maloang and Negeri Sohuwe, West Seram Regency, Maluku Province, and to understand what the legal basis and How to Have Land Ownership Rights According to Customary Law in the Taniwel Timur District, Maloang State and Sohuwe State, West Seram Regency, Maluku Province.

Results of the Research: In principle, ownership of land rights by a member or group of customary law communities, whether individual or communal / group, has a very binding power de jure and de facto. The principle of ownership in the provision of de jure guarantees in the sense that the customary law community recognizes that if ownership rights are obtained by means of the permission of the head of the association (Kepala Adat or Kepala Soa), to open and manage land for customary law communities it can be said to be a legal act that is legal according to law. adat as long as it does not contradict the prevailing customary law norms, and the principle of ownership in a de facto manner, namely that the principle of ownership has been obtained from generation to generation. This is what the local government must pay attention to in terms of recognition of rights by customary law communities in West Seram District, Maluku Province.
\end{abstract}

\footnotetext{
Abstrak

Latar Belakang: Kepulauan Seram Bagian Barat terdapat berbagai hak adat istiadat yang tumbuh dan berkembang di dalam kehidupan masyarakat hukum adat dan itu menjadi sebuah aturan yang diyakini oleh mereka, sehingga menjadi suatu hukum yang mengikat mereka dalam menentukan hak milik atas tanah adat mereka.

Tujuan Penelitian: Penelitian ini bertujuan untuk mengetahui bagaimana kedudukan hak milik atas tanah adat dalam sistem hukum tanah nasiona, dan apa landasan hukum dan cara terjadinya hak milik atas tanah adat menurut hukum adat.

Metode Penelitian: Penelitian ini menggunakan metode penelitian hukum normatif, yang bertujuan Untuk mengetahui bagaimana kedudukan hak milik atas tanah adat dalam sistem hukum tanah nasional di wilayah Kecamatan Taniwel Timur, Negeri Maloang dan
} 


\begin{abstract}
Negeri Sohuwe, Kabupaten Seram Bagian Barat Provinsi Maluku, dan Untuk memahami apa yang menjadi landasan hukum dan cara terjadinya hak milik atas tanah menurut hukum adat di wilayah Kecamatan Taniwel Timur, Negeri Maloang dan Negeri Sohuwe Kabupaten Seram Bagian Barat Provinsi Maluku.

Hasil Penelitian: Pada prinsipnya kepemilikan hak atas tanah oleh suatu anggota atau kelompok masyarakat hukum adat baik bersifat individu maupun bersifat komunal / kelompok mempunyai kekuatan yang sangat mengikat secara de jure maupun secara de fakto. Prinsip kepemilikan dalam pemberian jaminan secara de jure dalam arti bahwa masyarakat hukum adat mengakui apabila hak kepemilikan yang diperoleh secara izin kepala persekutuan (Kepala Adat atau Kepala Soa), untuk membuka dan mengelolah tanah bagi masyarakat hukum adat dapat dikatakan suatu perbuatan hukum yang sah menurut hukum adat sepanjang tidak bertentangan dengan norma - norma hukum adat yang berlaku, dan prinsip kepemilikan secara de fakto yaitu bahwa prinsip kepemilikan yang diperoleh itu, sudah diperoleh secara turun - temurun. Hal inilah yang harus diperhatikan oleh pemerintah daerah dalam hal pengakuan hak oleh masyarakat hukum adat di Kabupaten Seram Bagian Barat Provinsi Maluku.
\end{abstract}

\title{
1. Pendahuluan
}

Keberadaan masyarakat hukum adat merupakan bagian dari keberadaan Indonesia sebagai bangsa. Masyarakat hukum adat merupakan unsur esensial masyarakat hukum nasional dalam lingkup negara Republik Indonesia. Indonesia sebagai bangsa yang majemuk (plural) terdiri atas ratusan suku bangsa, bahasa, dan lingkungan masyarakat adat yang tersebar di ribuan pulau besar dan pulau kecil. Pada sebaran pulau besar dan pulau kecil inilah hidup masyarakat adat yang memiliki norma hukum tersendiri. Masyarakat adat yang merupakan lingkungan masyarakat yang masih sederhana dan melekat dengan alam (di sekitar hutan) menjadi bagian penting dari keberadaan bangsa Indonesia. ${ }^{1}$

Didalam kehidupan masyarakat hukum adat di wilayah kepulauan Seram Bagian Barat Kecamatan Taniwel Timur Negeri Maloang dan Negeri Sohuwe, untuk mempertahankan kehidupannya, mereka selalu bergantung kepada keberadaan tanah yang dianggap sebagai sumber penghidupan, atau dengan kata lain tempat berkembang biakan semua mahkluk ciptaan Tuhan Yang Maha Esa. Untuk itu tanah bagi masyarakat hukum adat di wilayah kepulauan Seram Bagian Barat Kecamatan Taniwel Timur Negeri Maloang dan Negeri Sohuwe Kabupaten Seram Bagian Barat Provinsi Maluku adalah suatu benda yang harus dijaga, dilestarikan, diamankan dengan demikian akan menjadi hak miliki mereka sendiri untuk kelangsungan hidup mereka.

Didalam Undang - Undang Pokok Agraria No. 5 Tahun 1960 Pasal 3 Bahwa:

"Pelaksanaan hak ulayat dan hak - hak yang serupa itu dari masyarakat - masyarakat hukum adat, sepanjang menurut kenyataannya masih ada, harus sedemikian rupa hingga sesuai dengan kepentingan nasional dan negara, yang berdasarkan atas

${ }^{1}$ Hendra Nurtjahtjo and Fokky Fuad, Legal Standing Kesatuan Masyarakat Hukum Adat Dalam Berperkara Di Mahkamah Konstitusi (Jakarta: Salemba Humanika, 2010), h. 3. 
persatuan bangsa serta tidak boleh bertentangan dengan undang - undang dan peraturan - peraturan lain yang lebih tinggi".

Sejalan dengan itu maka tanah sebagai objek lahan pengelolaan sumber daya alam mempunyai arti yang sangat penting dan strategis bagi kehidupan masyarakat hukum adat di wilayah kepulauan Seram Bagian Barat Kecamatan Taniwel Timur Negeri Maloang dan Negeri Sohuwe Kabupaten Seram Bagian Barat Provinsi Maluku, dan pembangunan sebagai sarana utama. Tanpa tanah tidak mungkin ada pembangunan infrastruktur, industry, perumahan, pariwista maupun perkebunan yang skala besar. Sebagian besar kehidupan masyarakatr hukum adat di wilayah kepulauan Seram Bagian Barat Kecamatan Taniwel Timur Negeri Maloang dan Negeri Sohhuwe Kabupaten Seram Bagian Barat Provinsi Maluku, sangat bergantung pada tanah. Dalam lingkungan masyarakat hukum adat di wilayah kepulauan Seram Bagian Barat Kecamatan Taniwel Timur Negeri Maloang dan Negeri Sohuwe Kabupaten Seram Bagian Barat Provinsi Maluku, tanah sangat istimewa kedudukannya, sebagai tempat mendirikan bangunan, tempat memberi makan, tempat mereka dikuburkan, mempunyai nilai spiritual dimana mereka dapat berhubungan dengan leluhurnya, ${ }^{2}$ karena pentingnya tanah bagi kehidupan masyarakat hukum adat di wilayah kepulauan Seram Bagian Barat Kecamatan Taniwel Timur Negeri Maloang dan Negeri Sohuwe, pemilikan hak atas tanah sesuai pula dengan kodrat hakikat manusia. Manusia pada hakikatnya besifat privat dan kolektif. Thomas Aquinas, seorang teolog dan filsuf ulung Abad Pertengahan mengatakan manusia menurut kodratnya bersifat individual dan sosial. Itulah sebabnya dalam pemilikan atas suatu benda, termasuk pemilikan atas tanah, kedua dimensi tersebut bisa terpadu secara harmonis. ${ }^{3}$

Namun berbeda halnya dengan terjadinya hak milik berdasarkan hukum adat yang hingga saat ini belum ada peraturan pemerintah yang diamanatkan pada Pasal 22 ayat (1) UUPA untuk mengatur mengenai terjadinya hak milik menurut hukum adat tersebut, untuk itu Pemerintah Daerah Kabupaten Seram Bagian Barat secara normative harus membuat sebuah legalitas pengakuan tentang perlindungan terhadap hak milik atas tanah adat di wilayah Kabupaten Seram Bagian Barat, sesuai dengan yang diamanatkan oleh Undang - Undang Pokok Agraria Pasal 22 ayat (1) yang berbunyi "terjadinya hak milik menurut hukum adat diatur dengan Peraturan Pemerintah". Sehingga hal ini tidak berpotensi menimbulkan multi tafsir mengenai hal tersebut yang cenderung berpotensi menimbulkan dampak negative bagi warga masyarakat hukum adat Kabupaten Seram Bagian Barat terkhusus masyarakat hukum adat di wilayah Kecamatan Taniwel Timur, Negeri Maloang dan Negeri Sohuwe dalam hal menguasai tanah berdasarkan hukum adat yang sudah menjadi landasan hukum dalam kehidupan sehari - hari secara turun temurun. Oleh karena itu perlu dilakukan kajian mengenai apa yang menjadi landasan hukum bagi masyarakat hukum adat di wilayah Kabupaten Seram Bagian Barat Kecamatan Taniwel Timur Negeri Maloang dan Negeri Sohuwe terkait dengan hak milik atas tanah adat, yang secara normative belum ada pengakuan dari Pemerintah Daerah Kabupaten Seram Bagian Barat Provinsi Maluku. Dan bagaimana cara terjadinya hak milik atas tanah menurut hukum adat selama peraturan pememerintah Kabupaten Seram Bagian Barat yang

${ }^{2}$ Adonia Ivone Laturette, “Hak Ulayat Dalam Hukum Tanah Nasional” (Universitas Airlangga, 2011), h. 1.

${ }^{3}$ Sony A Keraf, Hukum Kodrat Dan Teori Hak Milik Pribadi (Yogyakarta: Kanisius, 2001), h. 23. 
dimaksud belum lahir, serta bagaimana kedudukam hak milik yang terjadi berdasarkan hukum adat dalam sistem hukum tanah nasional.

\section{Metode Penelitian}

Penelitian hukum yang dipakai oleh penulis berdasarkan permasalahan yang diteliti adalah penelitian dengan metode penelitian hukum "normative". Metode penelitian hukum normatif atau penelitian hukum keputusan adalah metode atau cara yang dipergunakan dalam penelitian hukum yang dilakukan dengan cara meneliti bahan pustaka yang ada. ${ }^{4}$ Metode penelitian hukum normatif adalah suatu proses untuk menemukan aturan hukum, prinsip-prinsip hukum, maupun doktrin-doktrin hukum guna menjawab isu hukum yang dihadapi ${ }^{5}$. Tahapan pertama penelitian hukum normatif adalah penelitian yang ditujukan untuk mendapatkan hukum obyektif (norma hukum) yaitu dengan mengadakan penelitian terhadap masalah hukum. Tahap kedua penelitian hukum normatif adalah penelitian yang ditujukan untuk mendapatkan hukum subyektif (hak dan kewajiban). Sehingga dapat mengetahui kedudukan wilayah petuanan masyarakat adat di wilayah kepulauan terkhusus kepulauan Seram Bagian Barat, Kecamatan Taniwel Timur Negeri Maloang dan Negeri Sohuwe Kabupaten Seram Bagian Barat Provinsi Maluku, dalam aspek yuridis.

Barkaitan dengan permasalahan dan tujuan dari penelitian ini, yakni suatu penelitian yang terutama mengkaji ketentuan-ketentuan hukum positif, asas - asas hukum, prinsip prinsip hukum maupun doktrin hukum guna menjawab isu hukum yang dihadapi. Olehnya itu, penelitian ini selain utamanya mengkaji ketentuan - ketentuan hukum positif maupun asas-asas hukum akan tetapi juga menggunakan sedikit kajian hukum "Yuridis/sosiologis" yang bertujuan untuk mengkontruksikan tata hukum adat agar dapat mencari fakta dan pembenaran yuridis masalah atas permasalahan hukum, sehingga hasil yang akan dicapai kemudian memberikan persepsi mengenai apa yang seyogyanya atas permasalahan hukum dari penelitian yang dilakukan. Didalam penelitian hukum terdapat beberapa pendekatan, dengan pendekatan tersebut peneliti akan mendapatkan informasi dari berbagai aspek mengenai permasalahan yang sedang dicoba untuk dicari jawabannya. Macam-macam pendekatan-pendekatan yang digunakan dalam penelitian hukum adalah: 6 Pendekatan Undang-Undang (Statute pproach), Pendekatan historis (Historical approach), Pendekatan kompratif (Commparative approach), Pendekatan konseptual (Conseptual approach).

\section{Hasil dan Pembahasan}

\subsection{Kedudukan Hak Milik Atas Tanah Masyarakat Hukum Adat dalam Sistem Hukum Tanah Nasional}

Hukum Agraria Nasional bersumberkan pada hukum adat, dalam sistem hukum adat dikenal ada dua macam hak atas tanah yaitu:

\footnotetext{
4 Soerjono Soekanto and Sri Mamudji, Penelitian Hukum Normatif, Suatu Tinjauan Singkat, Jakarta: Raja Grafindo Persada (Jakarta: Rajawali Pers, 2015), h. 13-14.

5 Peter Mahmud Marzuki, Penelitian Hukum, (Jakarta: Kencana, 2016), https:/ /doi.org/340.072, h. 93.

${ }^{6}$ Marzuki. Ibid. h. 93.
} 
1) Hak atas tanah yang dikuasai secara bersama oleh suatu masyarakat adat, yang dalam istilah teknis yuridis disebut hak ulayat.

2) Hak tanah yang dikuasai secara perorangan.

Hak ulayat merupakan hak masyarakat hukum adat atas segala sumber daya agrarian (bumi, air, dan kekayaan alam yang terkandung di dalamnya). Hak ulayat lahir bukan karena diciptakan oleh putusan pejabat tetapi tumbuh dan berkembang (serta juga dapat lenyap) sesuai dengan keberadaan dan perkembangan kehidupan masyarakat hukum adat yang bersangkutan.

Pada dasarnya hak ulayat keberadaannya dalam UUPA adalah sudah diakui, akan tetapi pengakuan tersebut masih diikuti oleh syarat - syarat tertentu, yaitu, eksistensi dan mengenai pelaksanaanya. Oleh karena itu, hak ulayat dapat diakui sepanjang menurut kenyataan masih ada. Maksudnya adalah apabila di daerah - daerah dimana hak itu tidak ada lagi, maka tidak dihidupkan kembali.

Pelaksanaan tentang hak ulayat dalam UUPA diatur di dalam pasal 3 yang berbunyi sebagai berikut:

"Pelaksanaan hak ulayat harus sedemikian rupa, sehingga sesuai dengan kepentingan nasional dan negara, yang berdasrakan atas persatuan bangsa serta tidak bertentangan dengan Undang - Undang dan peraturan - peraturan lain yang lebih tinggi. Sesuai dengan apa yang diterangkan dalam penjelasan umum ( Angka H/3 ) disini ditegaskan pula bahwa kepentingan sesuatu masyarakat harus tunduk pada kepentingan nasional dan Negara yang lebih tinggi dan lebih luas".

Ada banyak perbedaan prinsip antara hukum tanah adat regional dan hukum agrarian nasional, yang tentu saja dapat menimbulkan konflik yang cukup serius. Dalam pembentukan UUPA 1960, hukum adat dijadikan landasannya, sedangkan hak ulayat merupakan salah satu dari lembaga - lembaga hukum adat dan kemudian dikembangkan kepada fungsi sosial dari hak - hak atas tanah. Pasal 5 UUPA mengatur bahwa: ${ }^{7}$

"Hukum Agraria yang berlaku atas bumi, air dan ruang angkasa ialah hukum adat, sepanjang tidak bertentangan dengan kepentingan nasional dan Negara, yang berdasarkan atas persatuan bangsa, dengan sosialisme Indonesia serta dengan peraturan - peraturan yang tercantum dalam undang - undang ini, dan dengan peraturan perundang perundangan lainnya, segala sesuatu dengan mengindahkan unsur - unsur yang berdasarkan pada hukum agama".

Lebih dari itu, dalam mukadimah UUPA 1960 dinyatakan: ${ }^{8}$

"Bahwa berhubungan dengan apa yang tersebut dalam pertimbangan - pertimbangan di atas perlu adanya Hukum Agraria Nasional, yang berdasar atas hukum adat tentang tanah, yang sederhana dan menjamin kepastian hukum bagi seluruh rakyat Indonesia, dengan tidak mengabaikan unsur - unsur yang berdasar pada hukum agama".

7 A P Parlindungan, Komentar Atas Undang-Undang Pokok Agraria (Bandung: Mandar Maju, 2008), h. 24.

8 Parlindungan. Ibid. 


\subsection{Landasan Hukum dan Cara Terjadinya Hak Milik Atas Tanah Adat Menurut Hukum Adat}

Indonesia sebagai Negara Agraria (pertanian) yang mempunyai sumber alam yang melimpah, akan tetapi kekayaan yang demikian besar sebagai karunia Tuhan Yang Maha Kuasa itu belum dapat dinikmati oleh rakyat, nampaknya kekayaan alam itu dimiliki oleh sebagian kecil orang Indonesia ${ }^{9}$. Negara Kesatuan Republik Indonesia yang berdasarkan UUD 1945 adalah Negara hukum (konstitusional) yang memberikan jaminan dan memberikan perlindungan atas hak-hak warga Negara, antara lain hak warga Negara untuk mendapatkan, mempunyai, dan menikmati hak milik. Hak milik atas tanah sebagai salah satu jenis hak milik, sangat penting bagi Negara, bangsa, dan rakyat Indonesia sebagai masyarakat agraria. Hak milik sebagai suatu lembaga hukum dalam hukum tanah telah diatur baik dalam hukum tanah sebelum UUPA maupun dalam UUPA.

Pasal 22 ayat (1) Undang-Undang Poko Agraria menyebutkan bahwa terjadi hak milik menurut hukum adat diatur dengan Peraturan Pemerintah lebih lanjut dalam penjelasan Pasal 22 disebut "sebagai missal dari cara terjadi hak milik menurut hukum adat ialah pembukaan tanah. Cara-cara itu akan diatur supaya tidak terjadi hal-hal yang merugikan kepentingan umum dan Negara".

Berdasarkan ketentuan tersebut dapat diketahui bahwa pengaturan mengenai terjadinya hak milik menurut hukum adat dimaksudkan agar tidak menimbulkan kerugian terhadap kepentingan umum dan Negara. Peraturan Pemerintah yang diamanatkan Undang-Undang Pokok Agraria selanjutnya di sebut UUPA tersebut hingga saat ini belum lahir sehingga belum mempunyai dasar hukum berupa ketentuan perundang-undangan mengenai cara terjadinya hak milik menurut hukum adat namun tidak berarti bahwa terjadinya hak milik menurut hukum adat tidak mempunyai landasan hukum. Dalam Pasal 5 Undang-Undang Pokok Agraria selanjtunya disebut UUPA disebutkan bahwa hukum agrarian yang berlaku atas bumi, air dan ruang angkasa ialah hukum adat, sepanjang tidak bertentangan dengan kepentingan nasional dan Negara, yang berdasarkan atas persatuan bangsa dengan sasialisme Indonesia serta dengan peraturan-peraturan yang tercantum dalam undang-undang ini dan dengan peraturan perundangan lainnya, segala sesuatu dengan mengindahkan unsur-unsur yang bersandar pada hukum agama. Oleh karena itu dalam hal belum ada ketentuan perundang-undangan yang mengatur mengenai cara terjadinya hak milik menurut hukum adat maka yang berlaku adalah hukum adat itu sendiri yang tentunya dengan pembatasan-pembatasan sebagaimana yang ditentukan dalam pasal 5 UUPA.

\subsection{Cara Terjadinya Hak Milik Atas tanah Adat Menurut Hukum Adat}

Hak milik atas tanah dapat terjadi melalui 3 (tiga) cara sebagaimana diatur dalam pasal 22 UUPA yaitu:

1) Hak milik atas tanah yang terjadi menurut hukum adat.

2) Hak milik atas tanah yang terjadi karena penetapan pemerintah.

\footnotetext{
${ }^{9}$ Suryani Sappe, Adonia Ivonne Laturette, and Novyta Uktolseja, "Hak Pakai Atas Tanah Hak Milik Dan Penyelesaian Sengketa," Batulis Civil Law Review 2, no. 1 (2021): 78-92, https://doi.org/10.47268/ballrev.v2i1.560.
} 
3) Hak milik atas tanah yang terjadi karena ketentuan undang - undang.

Namun dalam penelitin ini, penulis lebih memperhatikan hak milik atas tanah yang terjadi menurut hukum adat, terjadi hak milik atas tanah adat di wilayah Kecamatan Taniwel Timur Negeri Maloang dan Negeri Sohuwe Kabupaten Seram Bagian Barat Provinsi Maluku, berawal dari peperangan yang terjadi pada jaman dahulu yang mana terjadi peperangan itu karena terjadi perebutan wilayah kekuasan antara persekutuan masyarakat adat yang satu dengan masyarakat adat yang lain ( bukan yang berasal dari satu lingkungan persekutuan masyarakat adat) demi tempat tinggal dan untuk kelangsungan hidup mereka.

Dengan demikian siapa yang kuat dalam peperangan tersebut akan menguasai dan memiliki wilayah (termasuk tanah) yang sangat luas sesuai dengan batas kekuasaan berperang. Sebuah peristiwa yang terjadi jaman dahulu tumbuh dan terus berkembang seiring dengan perkembangan masyarakat adat, dan lahir menjadi suatu peristiwa hukum berdasarkan kebiasaan masyarakat adat, maka di jadikan sebagai suatu aturan hukum bagi masyarakat adat yang mereka yakini dan percayakan sebagai hukum dalam persekutuan masyarakat adat di negeri Maloang dan negeri Sohuwe sampai saat ini, terkait dengan hak milik atas tanah adat yang awal mulanya lahir dari hasil peristiwa peperangan antara sesama kelompok persekutuan masyarakat adat pada jaman dahulu.

Hak milik adat secara original tumbuh dan berkembang dari hak yang paling rendah tingkatannya, yaitu hak menandai tanah atau hutan. Pertumbuhan perkembangan hak tersebut berlangsung berdasarkan kaedah - kaedah hukum setempat. Dalam hukum tanah adat pulau Seram Kabupaten Seram Bagian Barat Kecamatan Tiniwel Timur Negeri Maloang dan Negeri Sohuwe, hak milik tumbuh dan berkembang dengan tahapan sebagai berikut:
a) Hak milik tanah Soa.
b) Hak milik tanah Marga.
c) Hak milik tanah Negeri.
d) Hak milik tanah Perseorangan / individu.

Penelitian ini penulis lebih mendepankan hak milik komunal atau hak milik bersama antara persekutuan masyarakat hukum adat di kedua negeri, setiap warga masyarakat hukum adat dapat dengan bebas menggunakan tanah sesuai dengan hak yang telah disepakati bersama dalam kelompok persekutuan masyarakat hukum adat di negeri Maloang dan negeri Sohuwe Kecamatan Taniwel Timur Kabupaten Seram Bagian Barat Provinsi Maluku.

Bagi anggota persekutuan yang bukan berasal dari kedua negeri ini tidak berkenaan untuk memiliki hak atas tanah yang dimilik oleh persekutuan masyarakat hukum adat di kedua negeri ini, namun apabila diberi ijin oleh kepala adat, raja negeri dan masyarakat adat maka dia bisa menggunakan tanah tersebut untuk bercocok tanam atau membuka usaha di tanah tersebut, namun satatus tanah yang di gunakan hanyalah sebagai hak pakai bukan menjadi hak milik karena tanah $\mathrm{u}=$ yang digunakan berstatus hak milik tanah adat, dan apabila dikemudian hari dikembalikan oleh lembaga adat maka mereka harus mengembalikannya kepada lembaga adat tanpa meminta pergantian kerugian kepada 
lembaga adat. Adapu tanah yang dimiliki oleh masyarakat hukum adat di gunakan untuk berkebun, dan di sewakan.

Menurut Maria S.W Sumardjono mengatakan hak ulayat sebagai istilah teknik yuridis adalah hak yang lekat sebagai kompetensi khas pada masyarakat hukum adat, berupa wewenang / kekuasaan mengurus dan mengatur tanah seisinya, dengan daya berlaku ke dalam dan keluar. ${ }^{10}$ Adapun hukum tanah adat sendiri adalah keseleruhan ketentuan ketentuan hukum, ada yang tertulis dan ada yang tidak tertulis, yang semuanya mempunyai obyek pengaturan yang sama, yaitu hak - hak penguasaan atas tanah sebagai lembaga - lembaga hukum dan sebagai hubungan - hubungan hukum konkrit, beraspek publik dan perdata, yang dapat disusun dan dipelajari secara sistematis, hingga keseluruhannya menjadi suatu kesatuan yang merupakan satu sistem

Tanah-tanah yang sudah di tetapkan berdasarkan kesepakatan bersama oleh Kepala Adat, Kepala Soa, dan Masyarakat Hukum Adat, tidak dapat dibatalkan lagi. Karena menurut aturan adat yang mereka yakini bahwa sesuatu yang sudah di putuskan atau sudah di sepakati bersama dalam pertemuan adat, sudah menjadi ikatan dan tidak dapat di batalkan dan di langgar oleh siapapun, dengan demikian maka tanah yang sudah di tetapkan dapat menjadi hak milik persekutuan masyarakat hukmum adat, dan tanah tanah tersebut diberi tanda batas. Benda - benda yang digunakan sebagai tanda batas yaitu:

1) Gunung.

2) Batu besar.

3) Pohon kayu yang besar.

4) Air atau kali.

Setiap tanah-tanah yang sudah diberikan tanda batas oleh persekutuan masyarakat hukum adat, batas tersebut tidak dapat dilewati oleh anggota persekutuan masyarakat lainnya, dan apabila di lewati batas yang sudah di berikan tanda, maka anggota persekutuan masyarakat hukum adat akan mendapat sanksi sesuai dengan aturan adat mereka. Bagi masyarakat hukum adat dapat dengan bebas mempergunakan tanah adat namun tidak dimiliki secara individu.

a. Hak Milik Tanah Soa.

Tanah Soa ini dimiliki oleh beberapa marga yang tergabung dalam soa tersebut, misalnya di desa Sohuwe Soa Latu ini terdiri dari beberapa marga yaitu, marga Sea, marga Latununuwe, dan beberapa marga pendatang yang kawin masuk ke negeri. Secara hak milik atas tanah adat di negeri ini, yang berhak atas tanah tersebut hanya meraka yang berada dalam persekutuan soa ini saja, tidak diperbolehkan maraga lain yang bukan berasal dari persekutuan soa tersebut masuk untuk memiliki tanah dalam persekutuan mereka, dengan demikian tanah milik soa hanya dapat di miliki oleh anggota persekutuan saja, tidak bisa di milik oleh anggota yang bukan berasal dari persekutuan soa tersebut.

${ }^{10}$ Maria S. W. Sumardjono, Kebijakan Pertanahan Antara Regulasi Dan Implementasi (Jakarta: Kompas, 2001), h. 55. 
Antara persekutuan dengan tanah yang mendudukinya itu hubungan yang erat sekali, hubungan yang mempunyai sumber serta yang bersifat religio-magis 11 . Hubungan yang erat dan bersifat religio-magis ini menyebabkan anggota persekutuan masyarakat hukum adat memperoleh hak untuk menguasai tanah yang dimaksud, memanfaatkan tanah itu, memungut hasil dari tumbuh-tumbuhan yang hidup diatas tanah itu, juga berburu terhadap binatang-binatang yang hidup disitu.

\section{b. Hak Milik Tanah Marga}

Tanah marga hanya di milik oleh marga - marga tertentu yang secara keturunan dia berasal dari marga tersebut. Tanah marga juga bisa dimiliki oleh anggota dari persekutuan soa, misalnya dalam soa latu atau soa besar terdapat marga marayate atau latununuwe, kedua marga tersebut juga bisa memiliki hak atas tanah adat yang berada dalam persekutuan marga. Untuk itu, tanah marga juga bisa di miliki oleh anggota persekutuan soa lain yang berstatus marganya yang sama.

c. Tanah Negeri atau Tanah Dati

Tanah ini di pergunakan untuk kepentingan bersama misalnya, ada seorang wanita atau pria yang kawin masuk mereka akan di ijinkan untuk menggunakan tanah negeri sebagai lahan bercocok tanam, namun kesemuaannya itu harus dengan ijin dari kepala adat, saniri negeri, raja negeri dan masyarakat setempat, tetapi tidak bisa di ambil sebagai hak miliknya, ( hanya bersifat hak pakai ). Hak negeri atas tanah ini disebut hak pertuanan atau hak ulayat. Seperti apa yang di amanatkan dalam pasal 6 Undang-Undang Negara Republik Indonesia No. 5 Tahun 1960 Tentang Peraturan Dasar Pokok-Pokok Agraria, bahwa "semua hak atas tanah mempunyai fungsi social".

\section{d. Tanah Perorangan / Individu}

Tanah milik perorangan ini lahir dari tanah marga, yang mana secara adat tanah tersebut sudah di berikan kepada seseorang dari marga tersebut untuk di miliki secara pribadi. Tanah milik perorangan ini juga lahir dari jual beli tanah adat antara masyarakat hukum adat dan juga masyarakat yang bukan masyarakat hukum adat setempat. Hak milik atas tanah dari seseorang masyarakat hukum adat yang membuka dan mengerjakan tanah itu pengertiannya adalah, bahwa warga yang mendiami tanah itu berhak sepenuh-penuhnya atas tanahnya tetapi dengan ketentuan wajib menghormati hak ulayat negerinya, di pandang dari perspektif hukum adat setempat.

Menurut Pasal 22 UUPA, hak milik menurut hukum adat harus diatur dengan peraturan Pemerintah supaya tidak terjadi hal-hal yang merugikan kepentingan umum dan Negara. Seorang warga persekuatan masyarakat hukum adat dari kedua negeri tersebut berhak untuk membuka lahan dan mengerjakan lahan itu terusmenerus dan menanam tanaman di atas tana tersebut sehingga sehingga ia mempunyai hak pakai atas tanah. Hak pakai ini dapat diperoleh meskipun hak

11 Johnny Ibrahim, Teori Dan Metode Penelitian Hukum Normatif (Malang: Malang: Bayu Media Publishing, 2006), h. 307. 
mengerjakan tanah itu praktis walaupun bertahun-tahun tidak menjadi persoalan bagi persekutuan masyarakat hukum adat.

Tanah adat yang berada dalam penguasaan dan kepemilikan secara komunal diatur sesuai dengan ketentuan hukum adat yang berlaku pada masing-masing wilayah hukum adat. ${ }^{12}$ Tanah petuanan adalah hak negeri terhadap seluruh petuanan dan merupakan hak atas tanah menurut hukum adat. Oleh karena itu semua anak negeri mempunyai hak untuk mempergunakan dan memanfaatkannya sebagaimana metinya berdasarkan ketentuan ketentuan adat di kedua Negeri tersebut (Negeri Maloang dan Negeri Sohuwe).

Pada prinsipnya kepemilikan hak atas tanah oleh suatu anggota atau kelompok masyarakat hukum adat baik bersifat individu maupun bersifat komunal / kelompok mempunyai kekuatan yang sangat mengikat secara de jure maupun secara de fakto. Prinsip kepemilikan dalam pemberian jaminan secara de jure dalam arti bahwa masyarakat hukum adat mengakui apabila hak kepemilikan yang diperoleh secara izin kepala persekutuan ( Kepala Adat atau Kepala Soa ), untuk membuka dan mengelolah tanah bagi masyarakat hukum adat dapat dikatakan suatu perbuatan hukum yang sah menurut hukum adat sepanjang tidak bertentangan dengan norma-norma hukum adat yang berlaku, dan prinsip kepemilikan secara de fakto yaitu bahwa prinsip kepemilikan yang diperoleh itu, sudah diperoleh secara turun-temurun. Hal inilah yang harus diperhatikan oleh pemerintah daerah dalam hal pengakuan hak oleh masyarakat hukum adat di Kabupaten Seram Bagian Barat Provinsi Maluku. ${ }^{13}$

\section{Kesimpulan}

Landasan yang menjadi dasar terjadinya hak milik adat atas tanah masyarakat hukum adat adalah prinsip-prinsip yang terdapat dalam sistem hukum adat pada umumnya dan kaedah-kaedah hukum adat setempat. Prinsip-prinsip atau asas-asas hukum adat pada umum terdapat sama dalam semua lingkungan hukum adat sedangkan kaedah-kaedah hukum adat setempat merupakan adat setempat merupakan hukum adat yang berlaku dalam suatu lingkungan tertentu yang dapat saja berbeda dengan lingkungan hukum adat lainnya. Secara substansi hak milik yang lahir berdasarkan hukum adat (hak milik masyarakat hukum adat) mempunyai kedudukan yang sama dengan hak milik yang lahir berdasarkan penetapan pemerintah (hak milik), perbedaannya hanya terletak pada bukti kepemilikan. Bukti kepemilikan hak milik atas tanah yang lahir berdasarkan hukum adat yaitu bukti penguasaan fisik dan pengakuan warga masyarakat hukum adat setempat, sedangkan bukti kepemilikan yang lahir berdasarkan penetapan pemerintah adalah berupa sertifikat. Karena itu apabila hak milik atas tanah masyarakat hukum adat didaftarkan kepada kantor pertanahan maka atas tanah tersebut akan diterbitkan juga sertifikat hak milik sebagaimana halnya hak milik yang lahir berdasarkan penetapan pemerintah.

\section{Referensi}

Ibrahim, Johnny. Teori Dan Metode Penelitian Hukum Normatif. Malang: Malang: Bayu Media

${ }^{12}$ Novyta Uktolseja, "Perkembangan Sistem Pewarisan Tanah Dati Di Ambon" (Disertasi: Universitas Airlangga, 2015), h. 65.

${ }^{13}$ Uktolseja. Ibid. h. 113. 
Publishing, 2006.

Keraf, Sony A. Hukum Kodrat Dan Teori Hak Milik Pribadi. Yogyakarta: Kanisius, 2001.

Laturette, Adonia Ivone. "Hak Ulayat Dalam Hukum Tanah Nasional." Universitas Airlangga, 2011.

Marzuki, Peter Mahmud. Penelitian Hukum,. Jakarta: Kencana, 2016. https://doi.org/340.072.

Nurtjahtjo, Hendra, and Fokky Fuad. Legal Standing Kesatuan Masyarakat Hukum Adat Dalam Berperkara Di Mahkamah Konstitusi. Jakarta: Salemba Humanika, 2010.

Parlindungan, A P. Komentar Atas Undang-Undang Pokok Agraria. Bandung: Mandar Maju, 2008.

Sappe, Suryani, Adonia Ivonne Laturette, and Novyta Uktolseja. "Hak Pakai Atas Tanah Hak Milik Dan Penyelesaian Sengketa." Batulis Civil Law Review 2, no. 1 (2021): 78-92. https:/ / doi.org/10.47268/ballrev.v2i1.560.

Soekanto, Soerjono, and Sri Mamudji. Penelitian Hukum Normatif, Suatu Tinjauan Singkat. Jakarta: Raja Grafindo Persada. Jakarta: Rajawali Pers, 2015.

Sumardjono, Maria S. W. Kebijakan Pertanahan Antara Regulasi Dan Implementasi. Jakarta: Kompas, 2001.

Uktolseja, Novyta. "Perkembangan Sistem Pewarisan Tanah Dati Di Ambon." Disertasi: Universitas Airlangga, 2015. 